\title{
Study of Intrinsic Vulnerability to Pollution by the GOD-Foster Method: Application to Temara Groundwater (Morocco)
}

\author{
Mariam Taazzouzte, Abdessamad Ghafiri, Hassan Lemacha, Saida El Moutaki \\ Faculty of Science Ben M'sik, Hassan II University, Casablanca, Morocco \\ Email: mariamtaazzouzte@gmail.com
}

How to cite this paper: Taazzouzte, M., Ghafiri, A., Lemacha, H., \& El Moutaki, S. (2020). Study of Intrinsic Vulnerability to Pollution by the GOD-Foster Method: Application to Temara Groundwater (Morocco). Journal of Geoscience and Environment Protection, 8, 129-145.

https://doi.org/10.4236/gep.2020.88010

Received: July 24, 2020

Accepted: August 28, 2020

Published: August 31, 2020

Copyright $\odot 2020$ by author(s) and Scientific Research Publishing Inc. This work is licensed under the Creative Commons Attribution International License (CC BY 4.0).

http://creativecommons.org/licenses/by/4.0/

\begin{abstract}
In Morocco, groundwater is of major importance in national economic poli$\mathrm{cy}$, that's why groundwater management programs are periodically installed to prevent their qualitative and quantitative degradation. Our work comes to contribute to this program by studying the inherent vulnerability to pollution of the Skhirate-Temara region (NW Morocco) using the GOD-Foster method. The latter defines the vulnerability of aquifers based on the resistance to pollutant penetration and the mitigation capacity of the underlying layer of the saturated zone while neglecting the lateral migration of pollutants into the saturated zone. The vulnerability map will delineate areas vulnerable to pollution and will serve as a decision-making tool to take the necessary action.
\end{abstract}

\section{Keywords}

Groundwater, Geograpgic Information System, Vulnerability, GOD-Foster Method

\section{Introduction}

In Morocco, groundwater is an important part of the country's water heritage (Belghiti et al., 2013), because of its importance in the field of drinking water supply or irrigation. However, the latter is experiencing an alarming deterioration due to the accelerated population and urban growth experienced by large cities such as Rabat, the political capital of the country, which belongs largely to our study area. To cope with this critical situation, many water quality management programs are installed on a regular basis and adapted to the socio-economic development and climate change that the country is experiencing.

In this sense, several research studies using effective tools such as geographic information systems have been developed to study the vulnerability of these wa- 
ters to pollution, with a view to delineating the most vulnerable areas, assessing pollution risk and creating vulnerability maps that constitute an essential information base facilitating decision-making (Sinan et al., 2003; Rahman, 2008; Ferrak et al., 2014; Arshad et al., 2019; Onwe et al., 2020).

There are many methods for assessing groundwater vulnerability to pollution (Neshat et al., 2014; Kumar et al. 2015; Rebolledo et al. 2016; Vidal Montes et al. 2016; Ribeiro et al. 2017; Ncibi et al., 2020), according to (Civita \& De Maio, 2004), they could be divided into three groups:

- Parametric system methods: GOD, EPIK, DRASTIC, SINTACS, CALOD, SI, COP.

- Methods of analog relationships and numerical models: AVI.

- Comparative methods: subdivided either according to the specific or intrinsic characteristics of the aquifer taken into account or according to the use or not of a weighting system for the criteria involved.

There are many reasons why one method should be chosen over another. For example, a method may be chosen because of the objectives of human activities and existing pollutants, or for practical reasons such as the availability of the required information (some methods require little data compared to others).

The choice of the method of establishing the groundwater vulnerability map to pollution depends on the quality and quantity of data manipulated. The aim of this work is to identify and delineate the different pollution zones through vulnerability maps that serve as a decision-making tool.

\section{Study Area}

The Skhirat Temara region (Figure 1) includes the city of Rabat, the political capital of the Moroccan Kingdom, and is part of the coastal strip of northern Morocco. The overall population of this area is 1,049,672 according to General Census of Population and Habitat, 2014 (ABHBC, 2019).

Its groundwater developed in the formations of the tertiary cover. It is a well-individualized water table on the hydrogeological level, it stretches for nearly $350 \mathrm{~km}$ and is inserted between the deep valleys of Oued Bouregreg and these tributaries of Oueds Akrach and Ikem and the Atlantic Ocean (Amraoui, 2000).

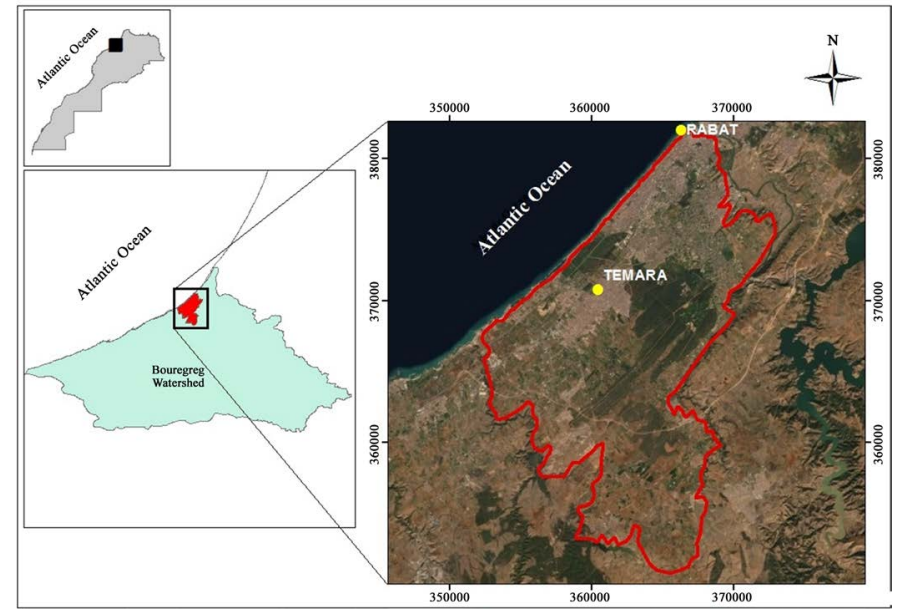

Figure 1. Geographical Location Map of Skhirat-Temara groundwater. 
The Temara groundwater is the main groundwater resource in the SkhiratTemara region. It has been used for many decades to meet the needs of various uses including the Potable Water Food in the center of Temara. It is also used for the irrigation of many plots exploited for the development of market gardening. It is characterized by a semi-arid climate with an average annual temperature ranging from $17^{\circ} \mathrm{C}$ to $18^{\circ} \mathrm{C}$, evaporation ranging from 1500 to 1600 $\mathrm{mm} /$ year, and irregular and low precipitation on a national scale $(\mathrm{ABHBC}$, 2019).

\section{Geological Context}

The Temara groundwater belongs to the coastal Meseta formed from highly pleated, tectonized and shaved primary lands (Combe, 1963). It features land (Figure 2) formed by:

- Thin sandstone benches topped with Plio-quaternary calcarenistic levels;

- Detritus yellow sands topped grey marls of the Mio-pliocene;

- Carboniferous limestone sandstone formations;

- Devonian reef or pre-reef limestone.

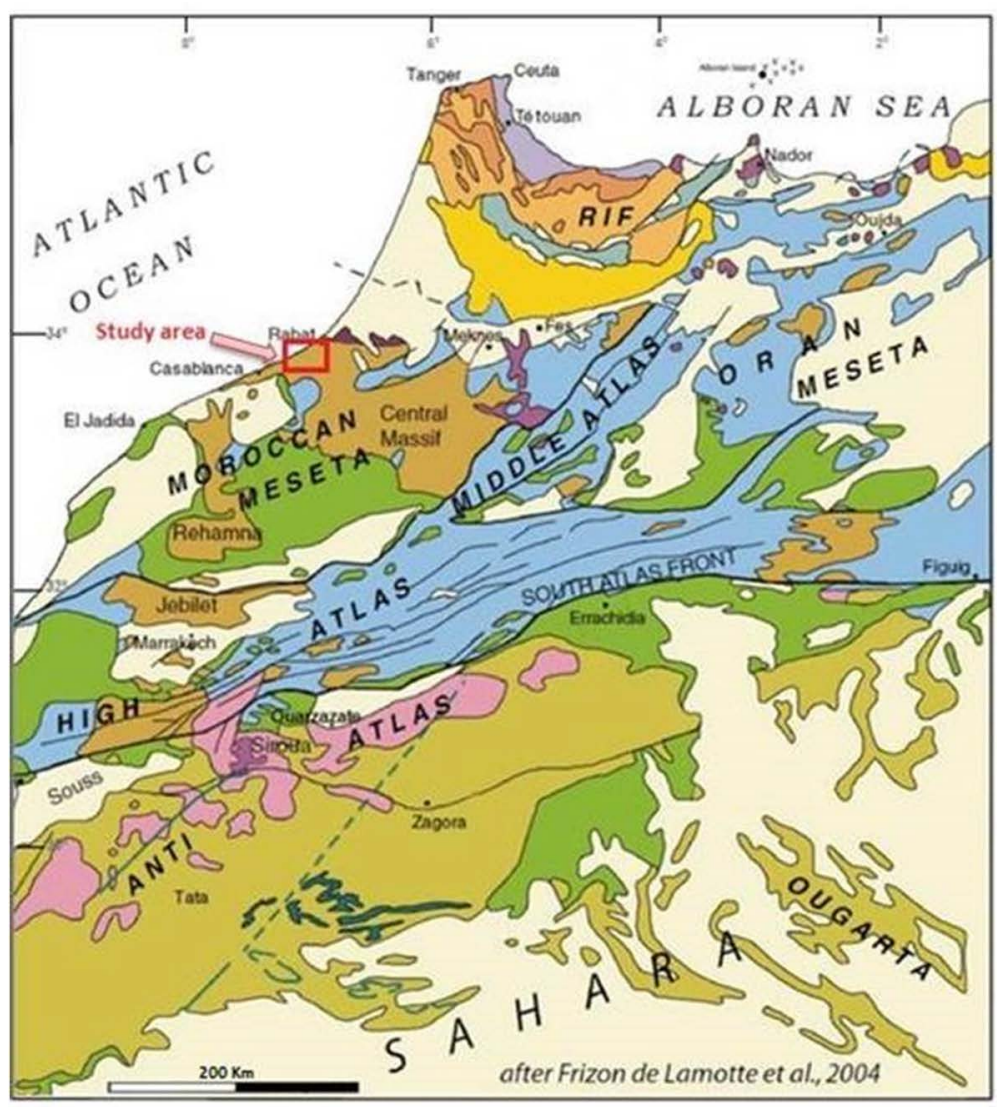

Legend

$\square$ Neogene - Quaternaire roches volcaniques $\square$ Neogen - Quaternaire roches sédimentaires

DOMAINE RIFAIN

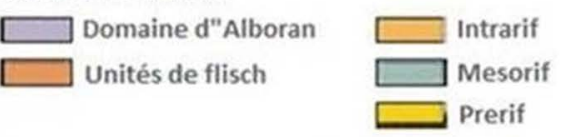

DOMAINE ATLASIQUE ET MESETIEN

$\square$ Crétcacé - Paléogène

$\square$ Trias - Jurassique

अ-aléozoîque a-Croûte varisque

$\square$ Précambrien

- Croûte calédonienne

DOMAINE SAHARIEN ET ANTI-ATLASIQUE

$\square$ Crétcacé - Paléogène

$\square$ Paléozoîque

$\square$ Précambrien

Dolérite triasique

$\square$ STUDY AREA

Figure 2. Geological map of coastal meseta (Frizon de Lamotte et al., 2004).

\section{Hydrogeological Context}

The Temara groundwater is well individualized from a hydrogeological point of 
view. There are three groundwater circulation zones (Figure 3) at the Temara groundwater (ABHBC, 2019):

- Zone A: which extends over the northern half of the Temara groundwater area, where water circulations occur in the sandstone, sand, limestone and sandy marls of the Plio-quaternary;

- Zone B: where the cover areas of the Plio-quaternary are completely pitted, and groundwater circulations are made in the altered fringe of the shale and the rights of fractures and faults;

- Zone C: which constitutes the natural extension of the second, water circulations, are done in the sandstones, sands and conglomerates of the Plio-quaternary and in primary shale and limestone.

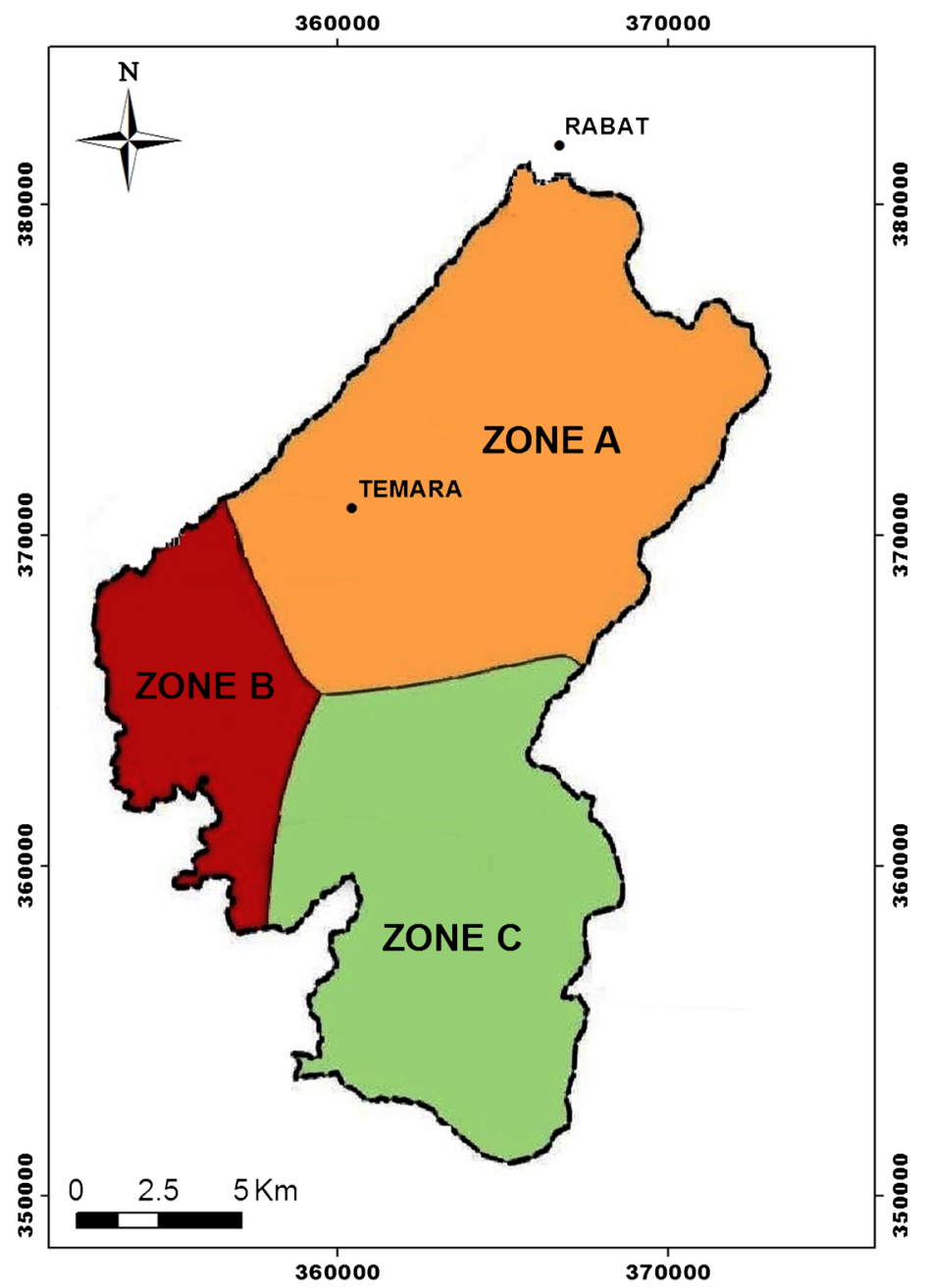

Figure 3. Distribution map of different hydrogeological zones (ABHBC, 2019).

Through the analysis of geological documents and reconnaissance survey data (85 wells) provided by Bouregreg and Chaouia Hydraulic Basin Agency (2019) for 85 wells (ABHBC) and the results of the field surveys carried out, we observed the presence of sedimentary gaps with lateral variation in places.

The depth of the groundwater does not usually exceed 20 meters (eastern, 
southern and western areas of the plain). The depth of more than 20 meters is located over large areas of the plain, particularly the central area of the study area (Figure 4).

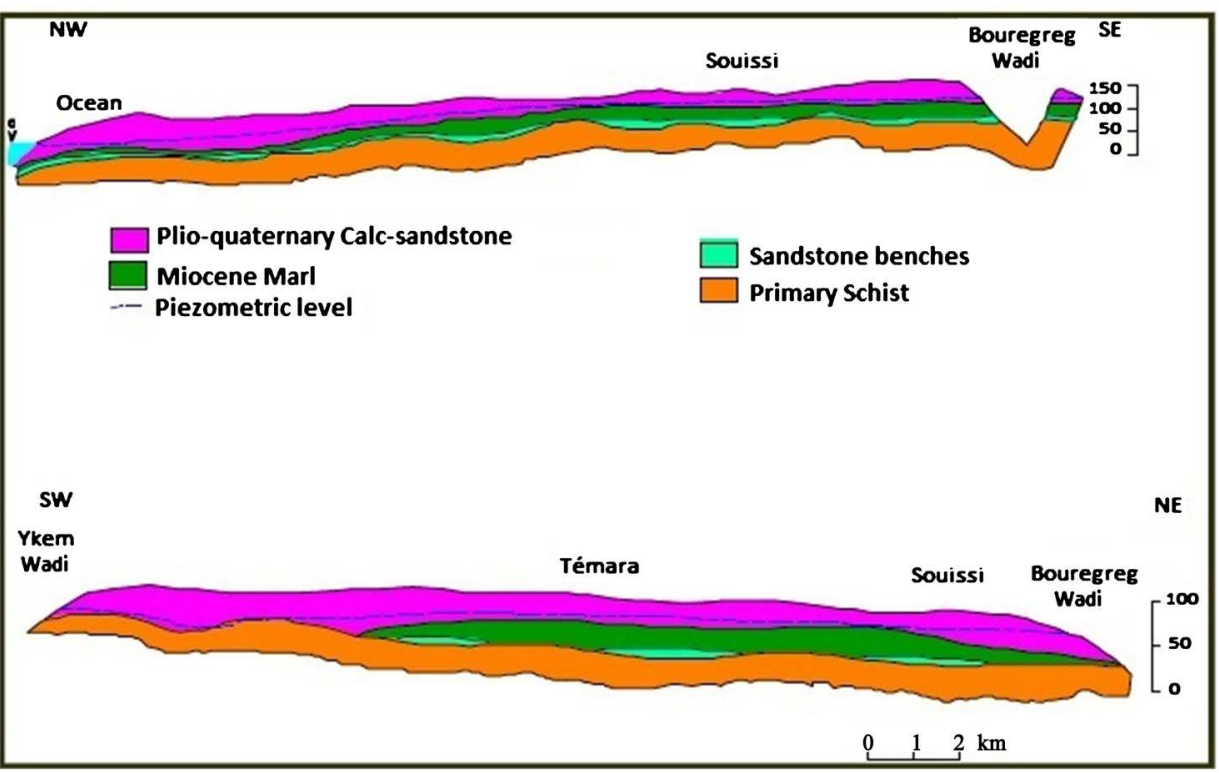

Figure 4. Lithological cuts of the study area (Amraoui, 2000).

The vulnerability index is therefore proportional to the permeability of aquifer formation. The values of the permeable selected generally vary between $10^{-2}$ and $10^{-4} \mathrm{~m} / \mathrm{s}$ and depend on the lithological nature of the facies. The recharge area of the groundwater is limited to an area of nearly $260 \mathrm{~km}^{2}$; recharge is estimated at $16 \mathrm{Mm}^{3} /$ year (ABHBC, 2019).

\section{Methodology}

The GOD-Foster method is the most widely used in assessing vulnerability to pollution, sedimentary aquifers. The GOD method (Groundwater occurrence "G", Overall class of aquifer ' $O$ ' and Depth to groundwater table ' $D$ ') was developed by Foster in 1987 presenting the vulnerability of the aquifer to the vertical percolation of pollutants across the unsaturated zone, while neglecting the lateral migration of pollutants in the saturated zone (Lobo Ferreira \& Oliveira, 2004; Fraga et al., 2013; Ghazavi \& Ebrahimi, 2015; Benabdelouahab et al., 2018; Boulabeiz et al., 2019).

The approach used for this three-parameter model:

- Type of aquifer depending on its degree of containment $\mathrm{C}_{\mathrm{a}}$,

- The depth of the groundwater $\mathrm{C}_{\mathrm{d}}$, shows the depth of unsaturated zone.

- The lithology of the aquifer $\mathrm{C}_{\mathrm{l}}$, determined the characteristics of the layers overlying the saturated zone of the aquifer with respect to their relative degree of porosity, permeability and to their water content.

The weights assigned to the classes of the different parameters are less than or equal to 1 . The GOD Index (GI), which assesses the vulnerability of the 
aquifer to pollution, is obtained by multiplying the three parameters (Murat et al., 2003).

$$
\mathrm{GI}=\mathrm{Ca} \times \mathrm{Cd} \times \mathrm{Cl}
$$

The following diagram (Figure 5) shows the steps taken to achieve the Skhirat-Temara groundwater pollution vulnerability map.

\begin{tabular}{|c|}
\hline \multirow[b]{2}{*}{$\begin{array}{l}\text { Very } \\
\text { Slight }\end{array}$} \\
\hline \\
\hline Slight \\
\hline Moderate \\
\hline High \\
\hline Very High \\
\hline
\end{tabular}

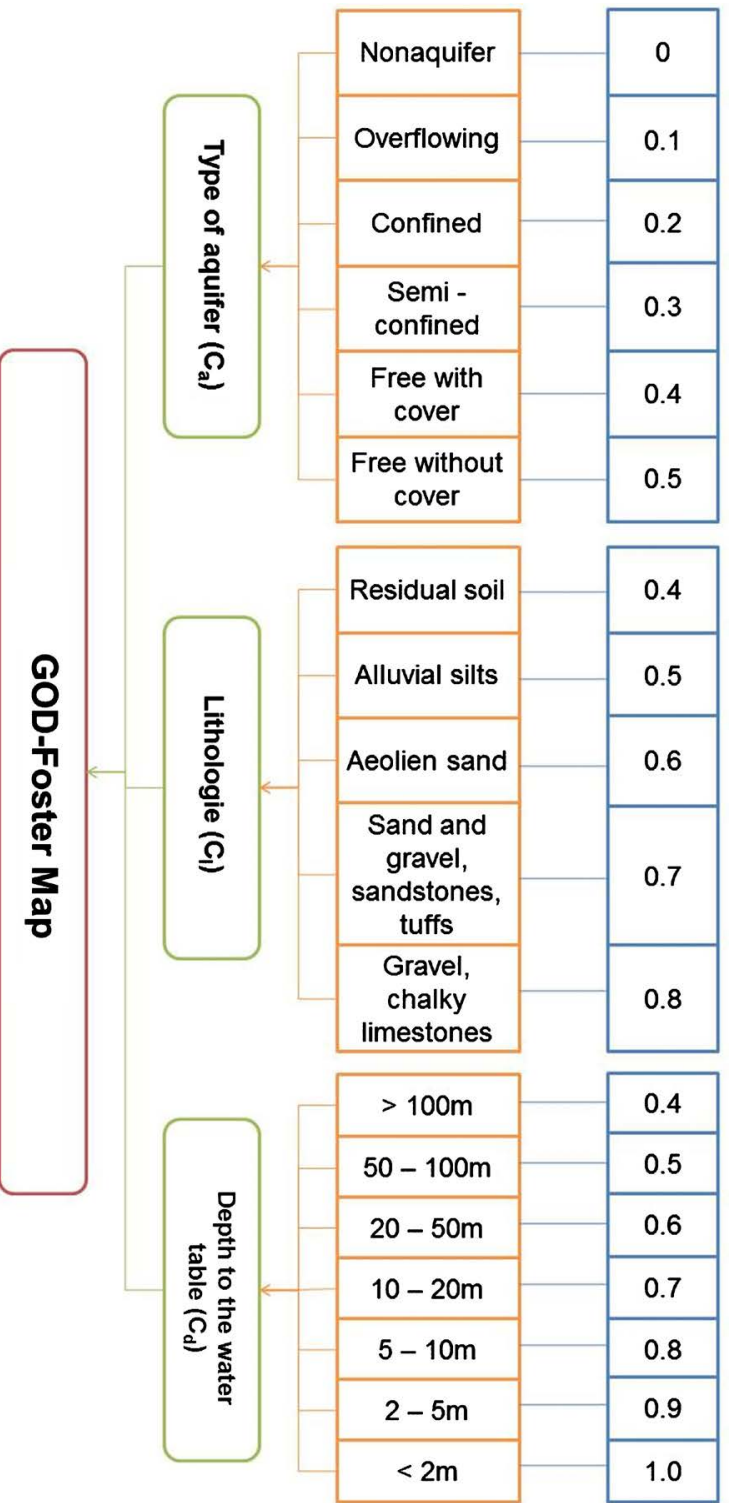

Figure 5. GOD-Foster method.

- aquifer criterion:

The purpose of this criterion is to identify the type of aquifer based on its degree of Ca containment. The Temara groundwater is a free tablecloth (Figure 6), linked very closely to the hydrological regime of the wadi. It flows uniformly to the sea, i.e. from the South East to the North West, a set of low plateaus inclined towards the coast (Combe, 1963). 


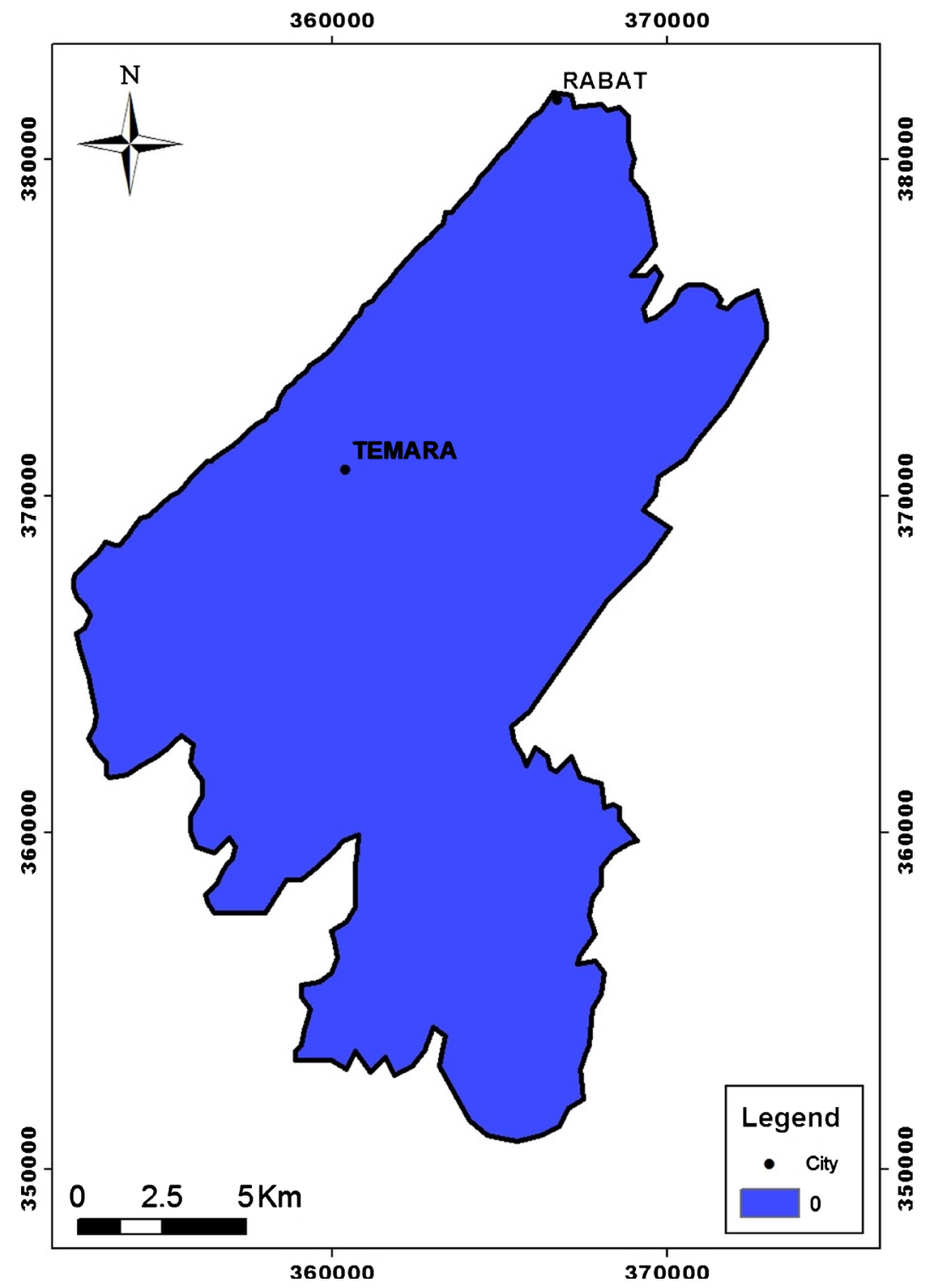

Figure 6. Skhirat-Temara groundwater criterion Map.

Criterion aquifer is an important criterion in the study of vulnerability, as any mitigation of the pollutant occurs in relation to depth. The depth of the aquifer was deduced based on the difference between the potential for elevation of the earth's surface $(\mathrm{Z})$ and the potential for elevation of the piezometric surface $(\mathrm{h})$.

- Depth criterion:

The groundwater has a variety at the depth of the water, covering the total area of the Basin, ranging from 0 to $234 \mathrm{~m}$, the depth levels are illustrated in the depth map (Figure 7) by the red color for the deep depths located at the level of Zone $\mathrm{C}$ and the southeastern part of Zone $\mathrm{A}$, and the green color for the low values that are scattered in some surfaces of zones A and B. That said, the most important depths exceeding $20 \mathrm{~m}$ extend in particular to the center of the study air. 


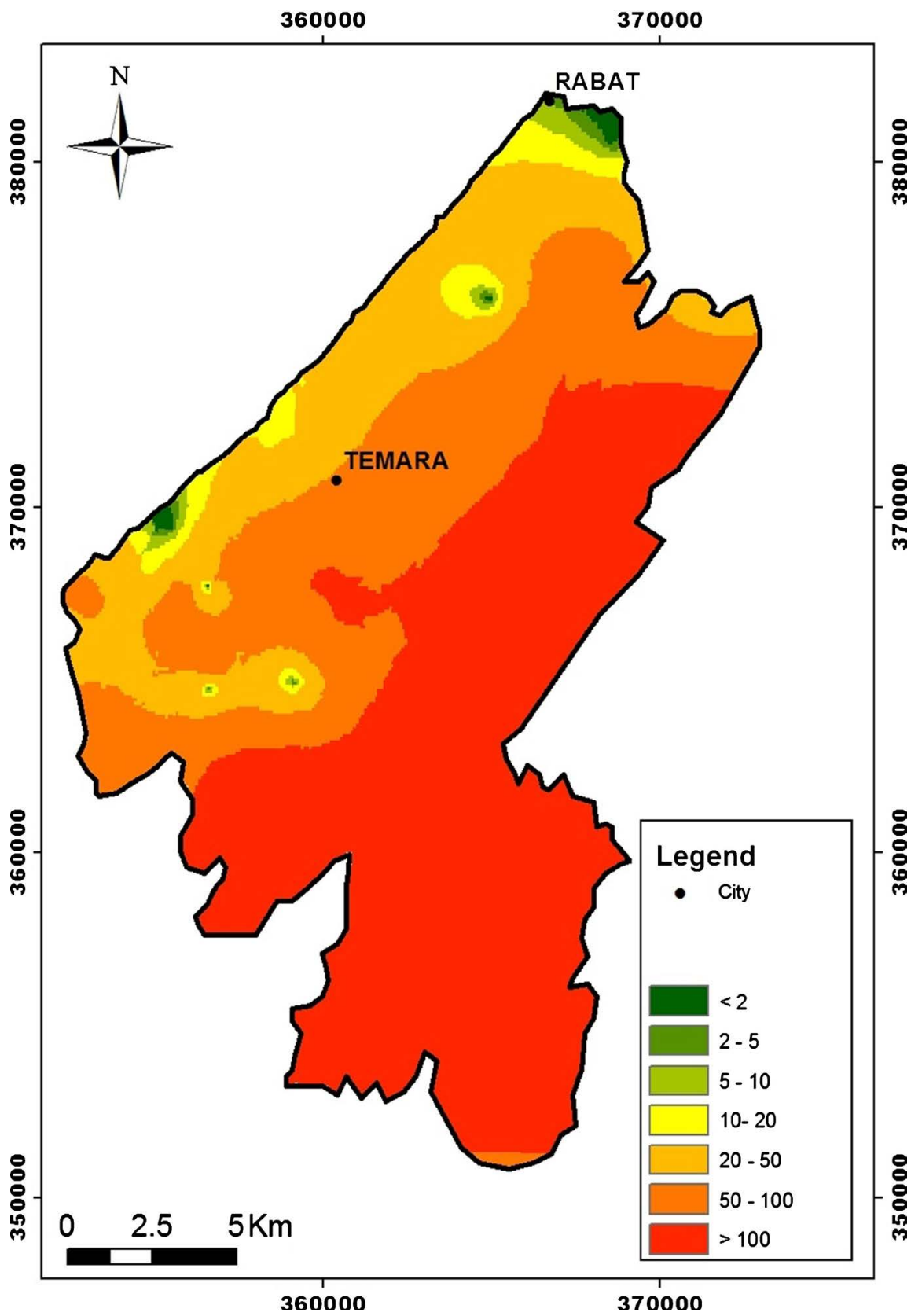

Figure 7. Depth Criterion Map of Skhirat-Temara groundwater.

\section{- Lithological Criterion:}

Criterion Map of the Temara groundwater is part of the coastal Meseta strip developed in the Tertiary cover (Figure 8).

It is a well individualized aquifer on the hydrogeological level is formed by:

- Thin, sandstone benches topped with Plio-quaternary calcarenistic levels;

- Detritus yellow sands topped grey marls of the Prepliocene self;

- Carboniferous limestone sandstone formations;

- Devonian reef or pre-reef limestone. 


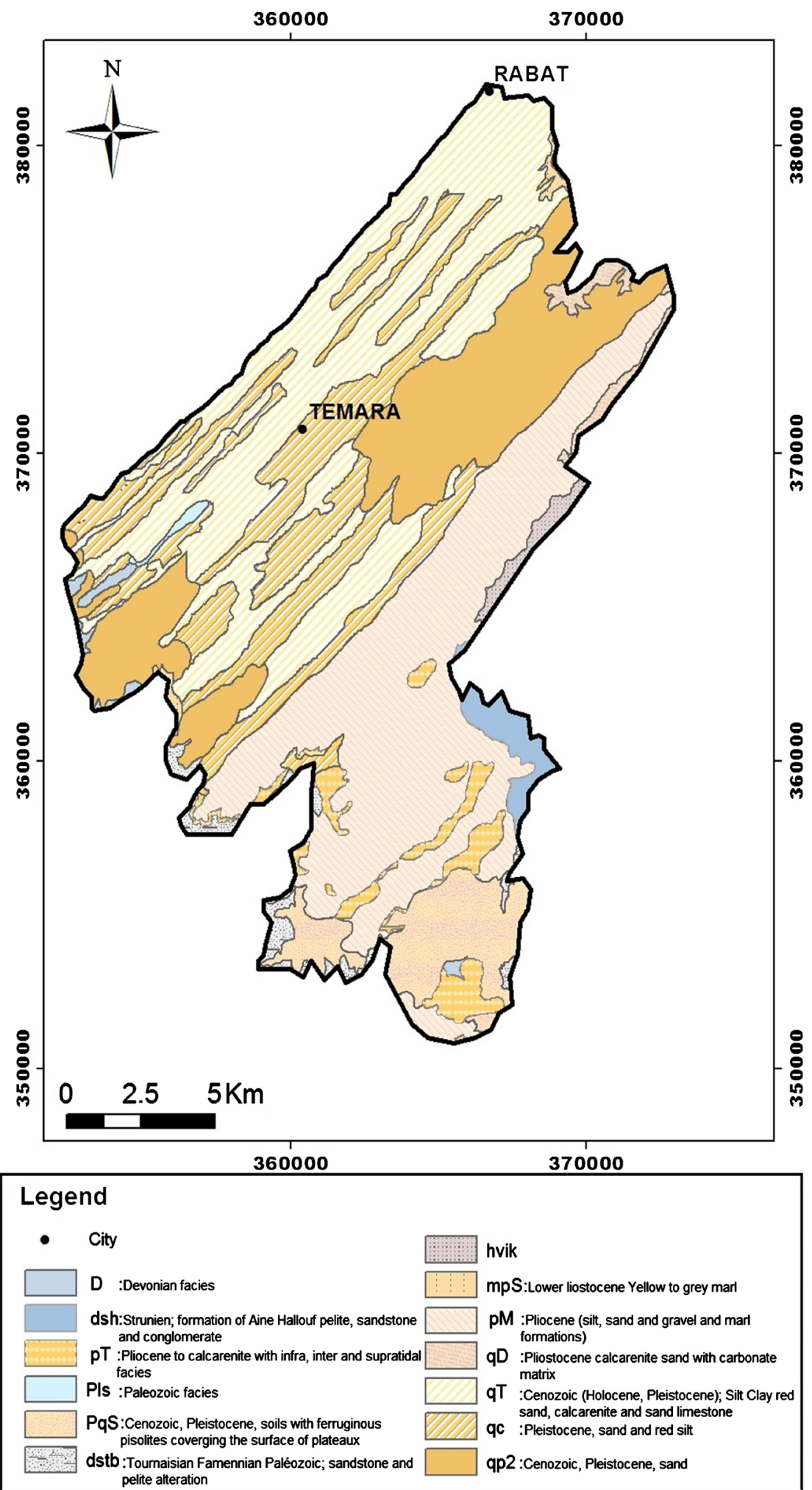

Figure 8. Lithological Criterion Map of Skhirat-Temara groundwater. 


\section{Results and Discussion}

The criterions that are introduced in the GOD-Foster method are weighted according to the following table:

Table 1. The criteria of the GOD-Foster method with weighting.

\begin{tabular}{|c|c|c|c|}
\hline & CRITERION & CLASSE & WEIGHT \\
\hline \multirow[t]{3}{*}{ G } & $\begin{array}{l}\text { Type of aquifer depending on its } \\
\text { degree of containment } \mathrm{Ca} \text {, }\end{array}$ & Free wthout cover & 1.0 \\
\hline & & Gravel, chalky limestones & 0.8 \\
\hline & & Sand and gravel, sandstone, tuffs & 0.7 \\
\hline \multirow[t]{6}{*}{$\mathrm{O}$} & The lithology of the aquifer $\mathrm{Cl}$ & Clay & 0.6 \\
\hline & & Alluvial silts & 0.5 \\
\hline & & Residual soil & 0.4 \\
\hline & & $<2$ & 1 \\
\hline & & $2-5$ & 0.9 \\
\hline & & $5-10$ & 0.8 \\
\hline \multirow[t]{4}{*}{$\mathrm{D}$} & The depth of the water table Cd & $10-20$ & 0.7 \\
\hline & & $20-50$ & 0.6 \\
\hline & & $5-100$ & 0.5 \\
\hline & & $>100$ & 0.4 \\
\hline
\end{tabular}

The Weight 1 was assigned for the first criterion, which is the type of aquifer, since it is a free without cover. For the second criterion, residual soil were affected by the value 0.4 followed by Alluvial silts 0.5 . The weight value 0.6 wa contributed to the clays, the sands and gravel, sandstone and tuffs were affected by the weight value 0.7 . While the weight 0.8 corresponds to the Gravel, chalky and limestones formations (Table 1). The maps below (Figures 9-11) show the results obtained based on the reclassification. 


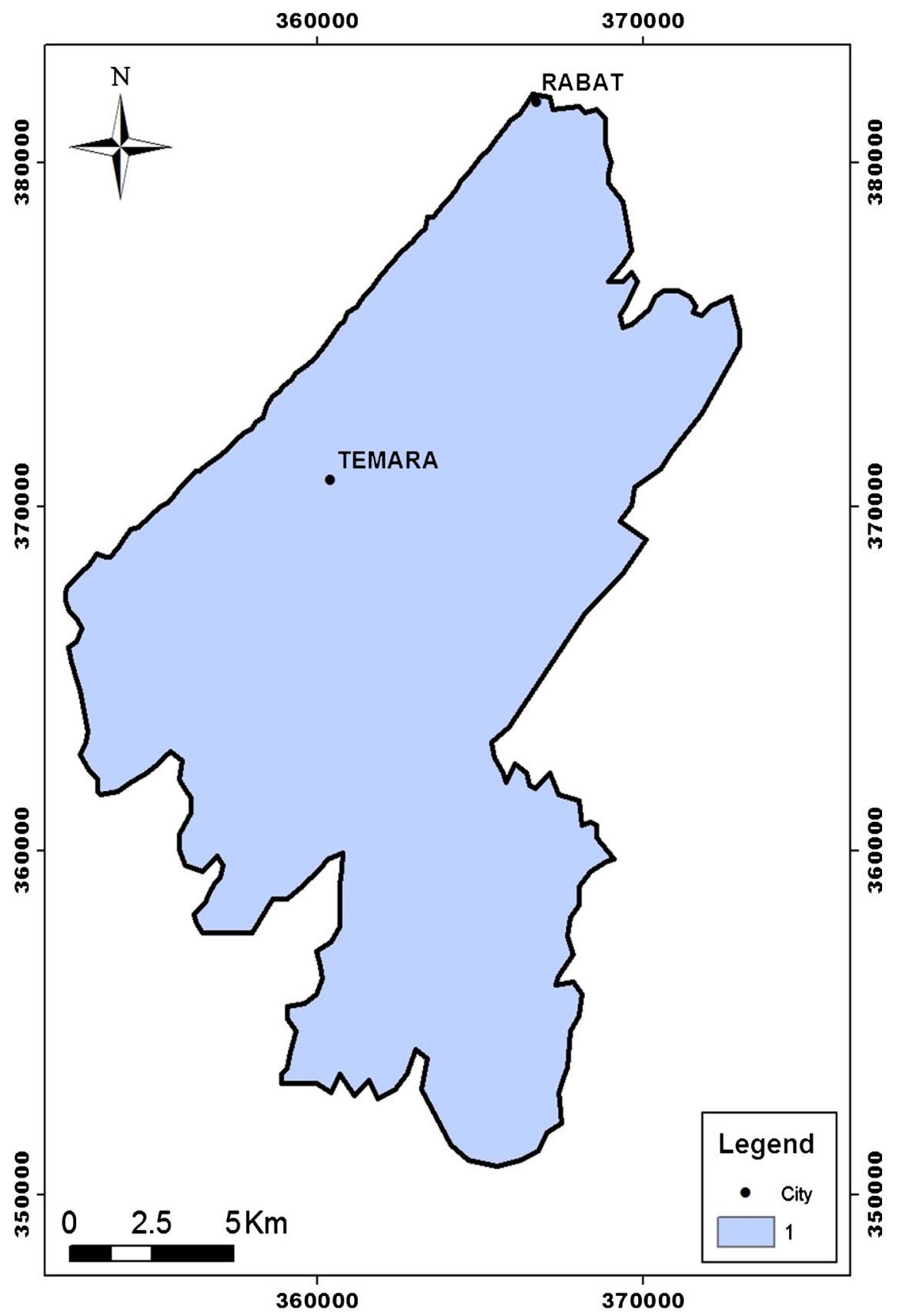

Figure 9. Reclassified Aquifer Type Map. 


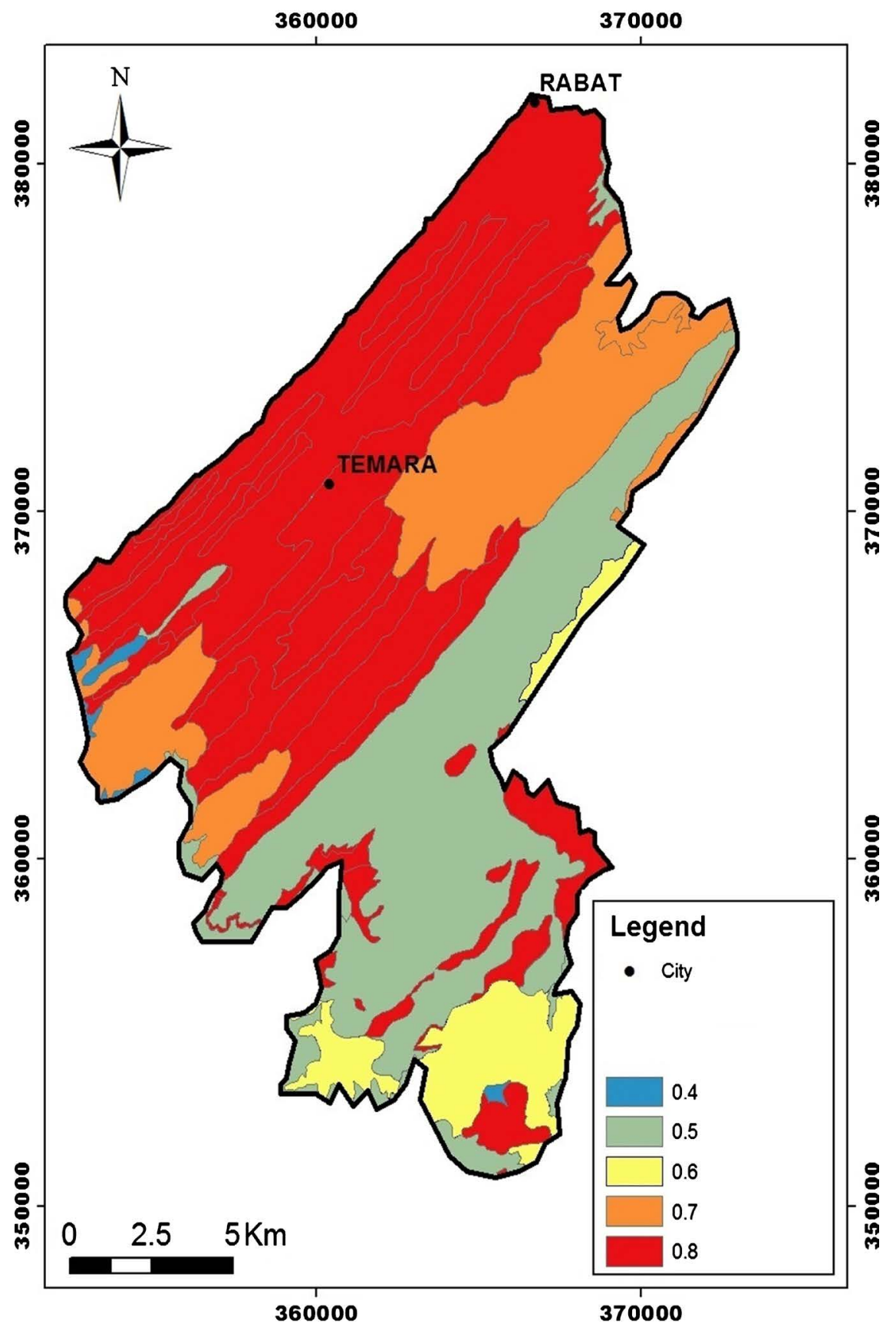

Figure 10. Reclassified lithology Map. 


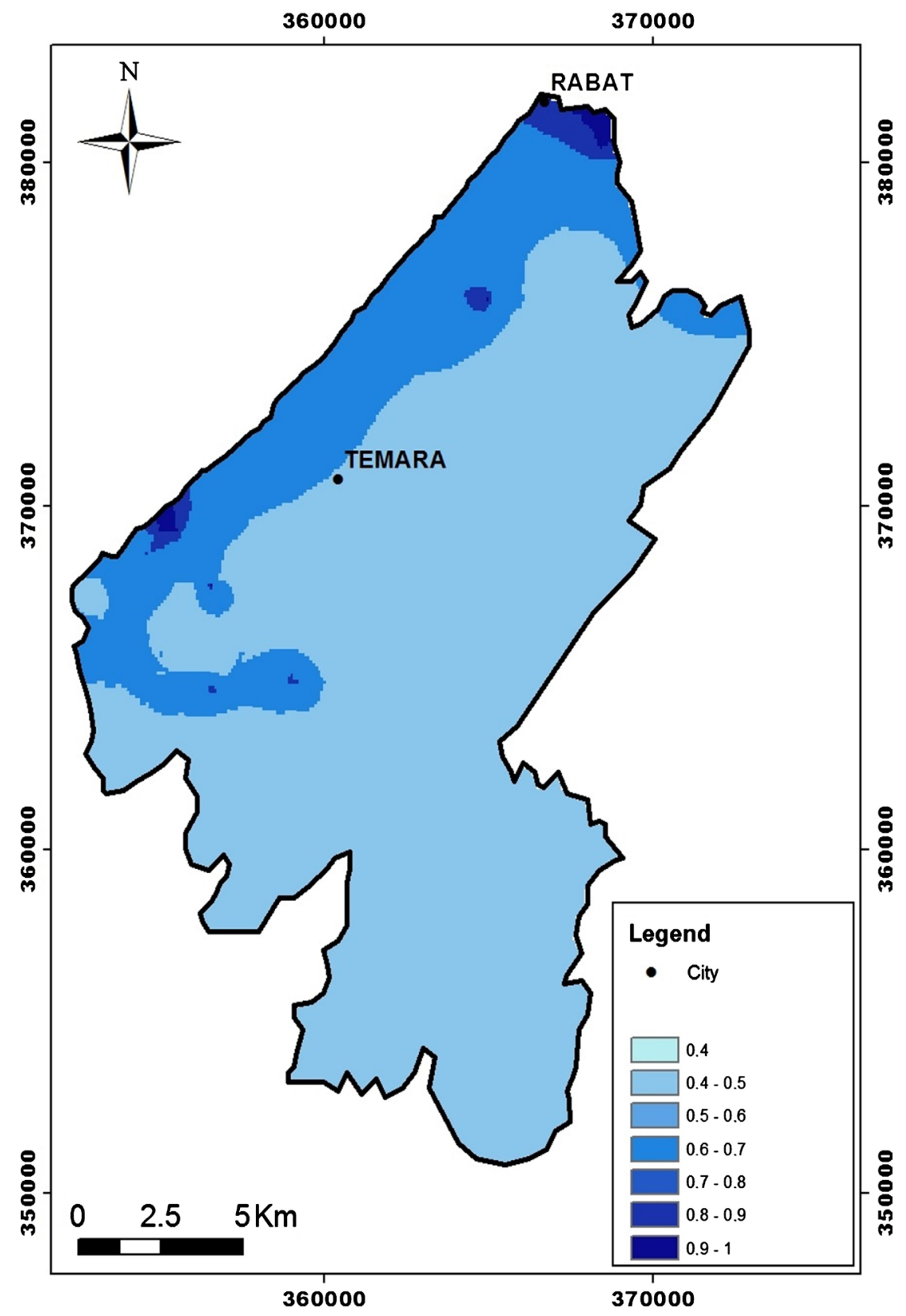

Figure 11. Reclassified Depth Map.

The earned vulnerability index (GI) ranges from 0.16 to 0.8 . Classes developed from the index (GI) identified five vulnerable classes (Figure 12): GI - 0.16 (Very slight vulnerability); 0.16 - GI - 0.3 (Slight vulnerability); 0.3 - GI - 0.5 (Moderate vulnerability); 0.5 - GI - 0.7 (High vulnerability); 0.7 - GI - 0.8 (Very high vulnerability). 


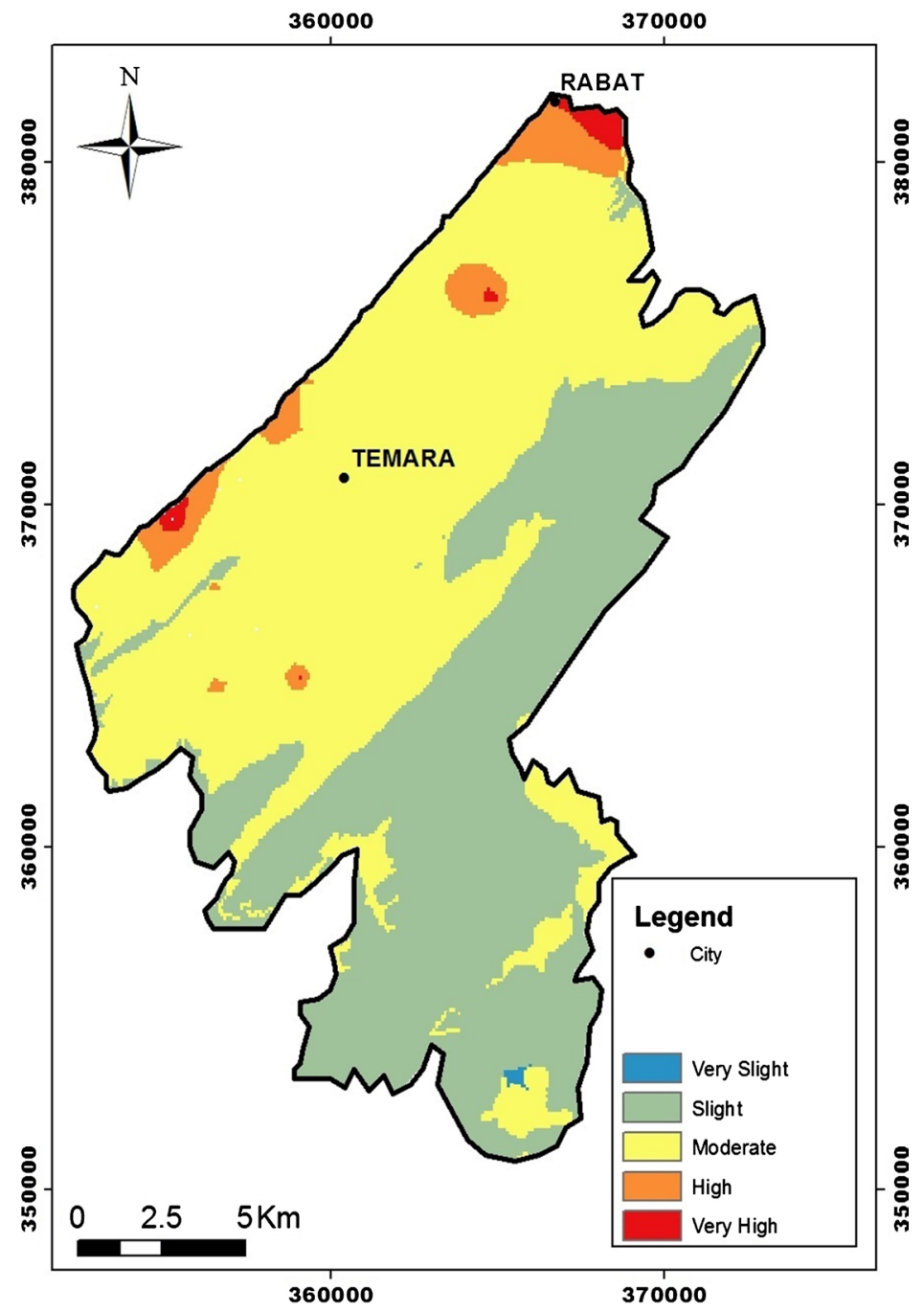

Figure 12. Skhirat-Temara Water Pollution Vulnerability Map.

The Very slight vulnerability class occupies a small area at the southern level of the study area. The Slight vulnerability class covers the entire southern part, the Moderate class covers the entire northern part. The High and Very high vulnerability classes are found in the north and northwest end. The variability of vulnerability to pollution noted is mainly related to the depth of no more than $20 \mathrm{~m}$ in the east, south and west of the groundwater, the direction of flow from the southeast to the northeast favors the overshoot of pollutants to the coast which increases the degree of vulnerability in this area. There are also disturbances at local levels related to overexploitation of the water table as well as lithology of the aquifer that usually forms sizzling limestone formations of the plio-quaternary with a marl substrate that forms an important cover of the groundwater. Thus, the very high vulnerabilities to pollution noticed at the level of the final map are present in the north (the cities of Rabat and Salé) especially at the mouth of the Oued Bouregreg, in the south-west (the city of Temara) and at the level of the STEP of Ain Atiq. 


\section{Conclusion}

Many programs and models for the management and monitoring of groundwater using new technologies such as geographic information systems have been developed with the aim of preserving the hydrogeological heritage. However, the latter require a large database to be able to develop thematic maps corresponding to the parameters of each model.

Our study focuses on the application of the GOD-Foster method which requires three criteria to study the vulnerability to pollution of groundwater. These criteria are generated from data from the Chaouia Hydraulic Basin Agency (ABHC) of 85 wells.

Mapping the inherent vulnerability to pollution of the Skhirat-Temara groundwater determined by the GOD-Foster method reveals high-vulnerability areas in the northwest near the mouth of Oued Bouregreg where wastewater discharges from the city of Rabat, salt and drinking water treatment plant gathers (Ain Atiq STEP). That said, the GOD-Foster method, although it only takes into account three criteria, namely; the type of aquifer, lithology and depth, it helps to delineate areas at risk, so it remains a considerable tool for decision-making and integrated management of groundwater resources.

\section{Acknowledgements}

The authors would like to thank the managers of the Bouregreg and Chaouia Hydraulic Basins Agency (ABHBC) for their collaboration and support. We also thank the anonymous reviews of our work.

\section{Conflicts of Interest}

The authors declare no conflicts of interest regarding the publication of this paper.

\section{References}

Amraoui, F. (2000). Etude hydrochimique des nappes de Témara et de la Chaouia côtière (Meseta marocaine). Bulletin de l'Institut Scientifique, 22, 71-80.

Arshad, A., Zhang, Z., Zhang, W., \& Dilawar, A. (2019). Mapping Favorable Groundwater Potential Recharge Zones Using a GIS-Based Analytical Hierarchical Process and Probability Frequency Ratio Model: A Case Study from an Agro-Urban Region of Pakistan. Geoscience Frontiers, 11, 1805-1819. https://doi.org/10.1016/j.gsf.2019.12.013

Belghiti, M. L., Chahlaoui, A., \& Bengoumi, D. (2013). Etude de la Qualite Physico-Chimique et Bacteriologique des eaux Souterraines de la Nappe Plio-Quaternaire dans la Région de Meknès (Maroc). Larhyss Journal, 14, 21-36.

Benabdelouahab, S., Salhi, A., Himi, M., Stitou El Messari, J. E., Casas Ponsati, A., Mesmoudi, H., \& Benabdelfadel, A. (2018). Using Resistivity Methods to Characterize the Geometry and Assess Groundwater Vulnerability of a Moroccan Coastal Aquifer. Groundwater for Sustainable Development, 7, 293-304. https://doi.org/10.1016/j.gsd.2018.07.004

Boulabeiz, M., Klebingat, S., \& Agaguenia, S. (2019). A GIS-Based GOD Model and Ha- 
zard Index Analysis: The Quaternary Coastal Collo Aquifer (NE-Algeria). Groundwater, 57, 166-176. https://doi.org/10.1111/gwat.12824

Bouregreg and Chaouia Hydraulic Basin Agency (ABHBC) (2019). Etude d'actualisation du plan directeur d'Aménagement Intégré des Ressources en Eau du bassin hydraulique du Bouregreg et de la Chaouia.

Civita, M., \& De Maio (2004). Italy Assessing and Mapping Groundwater Vulnerability to Contamination: The Italian “Combined” Approach. Geofísica Internacional, 43, 513-532.

Combe, M. (1963). Etude hydrogéologique de la région de Lalla Mimouna. Kenitra: National Office for Irrigation.

Ferrak, H., Hakdaoui, M., \& Fikri, A. (2014). Developement of Vulnerability through the DRASTIC Method and Geographic Information System (GIS) (Case Groundwater of Berrchid), Morocco. Journal of Geographic Information System, 6, 45-58. https://doi.org/10.4236/jgis.2014.61006

Fraga, C. M., Fernandes, L. F. S., Pacheco, F. A. L., Reis, C., \& Moura, J. P. (2013). Exploratory Assessment of Groundwater Vulnerability to Pollution in the Sordo River Basin, Northeast of Portugal. Rem: Revista Escola de Minas, 66, 49-58. https://doi.org/10.1590/S0370-44672013000100007

Frizon de Lamotte, D., Crespo-Blanc, A., Saint-Bezar, B., Comas, M., Fernadez, M., Zeyen, H., Ayarza, H., Robert-Charrue, C., Chalouan, A., Zizi, M., Teixell, A., Arboleya, M. L., Alvarez-Lobato, F., Julivert, M., \& Michard A. (2004). TRASNSMED-Transect I [Betics, Alboran Sea, Rif, Moroccan Meseta, High Atlas, Jbel Saghro, Tindouf Basin]. In W. Cavazza, F. M. Roure, W. Spakman, G. M. Stampfli, \& P. A. Ziegler (Eds.), The TRANSMED Atlas - The Mediterranean Region from Crust to Mantle. Berlin: Springer.

Ghazavi, R., \& Ebrahimi, Z. (2015). Assessing Groundwater Vulnerability to Contamination in an Arid Environment Using DRASTIC and GOD Models. International Journal of Environmental Science and Technology, 12, 2909-2918.

https://doi.org/10.1007/s13762-015-0813-2

Kumar, P., Bansod, B. K. S., Debnath, S. K., Thakur, P. K., \& Ghanshyam, C. (2015). IndexBased Groundwater Vulnerability Mapping Models Using Hydrogeological Settings: A Critical Evaluation. Environmental Impact Assessment Review, 51, 38-49. https://doi.org/10.1016/j.eiar.2015.02.001

Lobo Ferreira, J. P., \& Oliveira, M. M. (2004). Groundwater Vulnerability Assessment in Portugal. Geofisica Internacional, 43, 541-550.

Ncibi, K., Chaar, H., Hadji, R., Baccari, N., Sebei, A., Khelifi, F. et al. (2020). A GIS-Based Statistical Model for Assessing Groundwater Susceptibility Index in Shallow Aquifer in Central Tunisia (Sidi Bouzid Basin). Arabian Journal of Geosciences, 13, Article No. 98. https://doi.org/10.1007/s12517-020-5112-7

Neshat, A., Pradhan, B., \& Dadras, M. (2014). Groundwater Vulnerability Assessment Using an Improved DRASTIC Method in GIS. Resources, Conservation \& Recycling, 86, 74-86. https://doi.org/10.1016/j.resconrec.2014.02.008

Onwe, M. R., Nwankwor, G. I., Ahiarakwem, C. A., Abraham, E. M., \& Emberga, T. T. (2020). Assessment of Geospatial Capability Index for Siting Waste Dump/Landfill to Control Groundwater Geopollution Using Geographic Information System (GIS) Approach: Case Study of Abakaliki Area and Environs, Southeastern Nigeria. Applied Water Science, 10, 1-19. https://doi.org/10.1007/s13201-019-1087-5

Rahman, A. (2008). A GIS Based DRASTIC Model for Assessing Groundwater Vulnerability in Shallow Aquifer in Aligarh, India. Applied Geography, 28, 32-53. https://doi.org/10.1016/j.apgeog.2007.07.008

Rebolledo, B., Gil, A., Flotats, X., \& Sanchez Angel, J. (2016). Assessment of Groundwater 
Vulnerability to Nitrates from Agricultural Sources Using a GIS-Compatible Logic Multicriteria Model. Journal of Environmental Management, 171, 70-80.

https://doi.org/10.1016/j.jenvman.2016.01.041

Ribeiro, L., Pindo, J. C., \& Dominguez-Granda, L. (2017). Assessment of Groundwater Vulnerability in the Daule Aquifer, Ecuador, Using the Susceptibility Index Method. Science of the Total Environment, 574, 1674-1683.

https://doi.org/10.1016/j.scitotenv.2016.09.004

Sinan, M., Maslouhi, R., \& Moumtaz, R. (2003). Utilisation des SIG pour la caractérisation de la vulnérabilité et de la sensibilité à la pollution des nappes d'eau souterraine. Application à la nappe du Haouz de Marrakech, Maroc. Journal Hydrogéologie, BRGM (France), 4, 89-100.

Vidal Montes, R., Martinez-Graña, A. M., Martínez Catalán, J. R., Ayarza Arribas, P., \& Sánchez San Román, F. J. (2016). Vulnerability to Ground-Water Contamination, SW Salamanca, Spain. Journal of Maps 12, 147-155.

https://doi.org/10.1080/17445647.2016.1172271 